Simone de Beauvoir, Brigitte Bardot, and Back-Translation:

The Trajectory of Beauvoir's Discourse on the 'Eternal Feminine'

\title{
Pauline Henry-Tierney
}

Over the course of her lifetime and beyond, French philosopher Simone de Beauvoir has been heralded as many different personas: 'Beauvoir the feminist, Beauvoir the novelist, Beauvoir the memorialist'. 'Beauvoir the cinema enthusiast', however, is not one which readily springs to mind. Yet Beauvoir was an avid film lover, and at the height of her cinema-going she would watch three films per day. ${ }^{2}$ As a social commentator and witness to her time, she saw the important sociocultural value of film and its ability to represent lived experience, in particular to shine a light on the machinations of gender relations. She became fascinated by Brigitte Bardot, and in 1959 her article 'Brigitte Bardot and the Lolita syndrome' was first published in the American magazine Esquire in a translation by Bernard Frechtman. ${ }^{3}$ Deft in its analytical dissection of the Bardot myth, and paving an early theoretical path for feminist film theory, Beauvoir's article is of interest for its unusual linguistic and cultural crisscrossing, since it was not only initially published in translation, but also back-translated into French in 1979 and anthologized in $2015 .{ }^{4}$ Tracing the translational trajectory of Beauvoir's text, this essay aims to shed light on the contextual details which prompted its various iterations within different cultural and temporal spaces. As a case study, it also seeks to probe the dynamics of literary back-translations to consider how they disrupt traditional hierarchies subjugating a translation to its original, and threaten the viability of such a model. Finally, the role of paratexts will be discussed, when analysing how the inclusion of certain photographs of Bardot in certain versions of Beauvoir's text functions as a form of intersemiotic translation.

In the late 1950s and early 1960s Brigitte Bardot was at the height of her career. 
Fashioned through roles in films such as Roger Vadim's Et Dieu créa la femme (1957) and Jean-Luc Godard's Le Mépris (1963) as a symbol of the hedonistic, carefree youth emerging from a postwar France, Bardot was celebrated and denounced in equal measure for her exuberance and excesses. As Ginette Vincendeau observes:

In her taboo-breaking representation of femininity on screen and her own sexually free behaviour off screen, Bardot was a revolution, a controversial and in many ways given the constraints on women's legal rights, not to mention bans on contraception and abortion - an 'impossible' role model for women in the audiences of the time. ${ }^{5}$

Her appeal was not limited to France but extended internationally, prompting what Kelley Conway describes as a 'truly voluminous discourse about her' in the United States. ${ }^{6}$

Ultimately, Bardot embodied a breaking away from patriarchal hegemonic configurations of women in the $1950 \mathrm{~s}$, and it is precisely this persona which sparked Beauvoir's fascination. As Ursula Tidd states, 'Beauvoir is interested in the disruptive erotic power of Bardot as a combination of "femme fatale" and "nymphette" .,7

Building upon her earlier work on myth in Le Deuxième Sexe, in 'Brigitte Bardot and the Lolita syndrome' Beauvoir presents Bardot as the incarnation of the myth of the 'Eternal Feminine'. A myth, Beauvoir contends, based upon a set of ahistorical absolutes placing women in a position of asymmetrical reciprocity in relation to men. Yet, as traditional gender roles start to become unhinged in a society evolving due to women's liberatory gains, the myth must be revisited in order to redress the status quo. As Beauvoir writes in this text, 'The adult woman now inhabits the same world as the man, but the child-woman moves in a universe which he cannot enter. The age difference re-establishes between them the distance that seems necessary to desire. ${ }^{8}$ Beauvoir calls this the 'Lolita syndrome'. An allusion to 
Vladimir Nabokov's pre-pubescent object of desire and a reworking of the Cinderella myth, ${ }^{9}$ it depicts the child-woman as the passive body-object concretized through the desiring male gaze, whose childlike innocence alleviates masculine fears of female sexual autonomy. Yet, while Bardot appears to conform to this reworking of the old myth via the image of her manufactured by Vadim's films, as Beauvoir writes, 'Her eroticism is not magical, but aggressive. In the game of love, she is as much a hunter as she is a prey. The male is an object to her, just as she is to him. And that is precisely what wounds masculine pride. ${ }^{, 10}$ Bardot's persona as a desiring being thus requires the spectator to acknowledge the reciprocal exchange of embodied consciousnesses in the erotic encounter. ${ }^{11}$ Recognizing Bardot's subjective agency comes with an emasculating counter-effect which, according to Beauvoir, repels the average Frenchman, who prefers to maintain authority by reducing women to controllable objects. American men, on the other hand, are more amenable to Bardot's persona since 'the sexual equality that B.B.'s behaviour affirms wordlessly has been recognized in America for a long time'. ${ }^{12}$

Beauvoir's text was commissioned by Esquire, the American magazine catering 'to an audience of upscale gentlemen'. ${ }^{13}$ Founded in 1933, the magazine, still published to this day, went through several phases reflecting changing editorial leadership. Featuring contributions from literary figures and cultural commentators, it pioneered new journalism before becoming more lifestyle-oriented and returning to its classical roots in 2016. The magazine had a strong cultural focus when Beauvoir's article on Bardot was published alongside a piece by François Mauriac. The fact that Esquire should ask her to author this text signals, as Tom Kemper argues, 'a "mentalité” linking the French New Wave to philosophical provocauteurs like Beauvoir'; 'her author-ity licenses philosophical discussions of European art films' ${ }^{14}$ In this sense, then, even before any discussion of the text's translation into English, we can consider Beauvoir's article as a form of 'cultural translation'. Beauvoir is 'translating' 
or mediating the cultural phenomenon of Bardot for an American audience eager to learn more about the nouvelle vague, seen as a cultural articulation of a European post-war wave of eroticism. Beauvoir is also 'translating' her own philosophical discourse for the common reader. Deploying a cultural and sociological analysis of the Bardot persona allows Beauvoir to probe deep-seated questions about the reification of women through myths fashioned by patriarchal agendas, whose apparent fixity can be jeopardized when these myths become open to transmogrification. Denise Warren quite rightly classifies Beauvoir's article as an 'export-text'; ${ }^{15}$ just as Beauvoir considers Bardot as important a French export as Renault cars, so too we must consider how Beauvoir's article itself functions as an export. To succeed, an export must have a hospitable market and any perceived barriers to its successful launch must be negotiated. A text in which Beauvoir mobilizes the iconoclastic image of Bardot to debunk the myth of the 'Eternal Feminine', thus disempowering its male creators, would not have found resonance with a male readership had Beauvoir not made such a clear distinction in what she saw as the differences between the American man and his more misogynist French counterpart. Here Beauvoir's target audience is very specific, and perhaps this is a reason why her article did not appear simultaneously in an equivalent French publication.

Beauvoir's text was translated into English by Bernard Frechtman in 1959. An American translator who had been living in France for twenty years, Frechtman had translated works by Jean-Paul Sartre and Albert Camus, and he was the official translator of Jean Genet. In his obituary in the New York Times he is described as 'an intimate of the postwar writers of France', 'a well-known member of the literary and theatrical world here'. ${ }^{16}$ In 1948 Frechtman translated Beauvoir's Pour une morale de l'ambiguïté (1947). Grounded in existentialist ethics, Beauvoir's exploration of ambiguity as 'the tension between seemingly opposing experiences of the self as both a free subject and an object for others ${ }^{, 17}$ dovetails 
with her conceptualization of Bardot's position in the article she would write for Esquire. The philosophical intermeshing between these two texts would qualify Frechtman as an appropriate choice of translator for this later work. Perhaps still more important was Frechtman's nationality. As an American, what better envoy to usher Beauvoir's text on Bardot into this different cultural landscape?

A closer examination of Frechtman's translation reveals the instrumental role he played in culturally assimilating Beauvoir's voice to make her palatable for the target audience. In English, Beauvoir talks about 'high-minded folk' and 'a cloud of ballyhoo', and describes Bardot's persona as 'the little rascal'. ${ }^{18}$ Such colloquialisms, in keeping with the informal American parlance of the era, bring Beauvoir closer to her American readers. To borrow Lawrence Venuti's notion of domestication, Beauvoir's vocabulary is domesticated for her American readership to downplay her foreign alterity and add further credence to her argument. Furthermore, the films Beauvoir references in her text - Et Dieu créa la femme, Les Liaisons dangereuses, L'amour est mon métier, S’il vous plaît, Monsieur Balzac, or Babette s'en va-t-en guerre - are only ever referred to by their English titles, giving the impression that they did not previously exist in their French versions, which again plays into a translation strategy of assimilation, only this time not to assimilate Beauvoir but Bardot. Beauvoir's study of the Bardot persona and the implications it bears for how we interpret self/Other relations becomes all the more compelling when we feel more closely connected to Bardot herself.

Frechtman's strategy of implicating the reader by domesticating his translation is illustrated in the following example. At a point in the text where Beauvoir explicitly refers to American men's penchant for Bardot's nymph-like qualities, to the exclusion of other interpretations of the new woman such as the more autonomous figures of wife and mother, Frechtman creates even deeper resonance for Beauvoir's point by directly situating the 
American male reader as her intended addressee through his culturally specific choice of vocabulary: "He abandons himself eagerly to the charms of the "nymph" in whom the formidable figure of the wife and the "Mom" is not yet apparent. ${ }^{, 19}$ Without access to Beauvoir's original French text, it is difficult to speculate about the reasons behind Frechtman's alterations, but the absence of the original certainly throws into contention the status of his translation. With no French original circulating in France, how are we to understand the relationship between source and target text? Undeniably, Frechtman translated the text, but how appropriate is it to use the word 'translation'? In terms of function, it is akin to our preconception of originals as superior and stable entities. We need to travel forwards twenty years to the publication of the text in French to learn more about Frechtman's translation.

Beauvoir's text first appeared in French in 1979 in Claude Francis and Fernande Gontier's volume Les Écrits de Simone de Beauvoir published by Gallimard. A volume which the editors describe as both a biography and a bibliography, its aim is to rejoin Beauvoir's thought with her praxis, signalling the close relationship between what the philosopher wrote and experienced. The collection presents texts which Beauvoir wrote in French, or which were released in other languages, and which had previously remained unpublished or difficult to access. One such text is 'Brigitte Bardot and the Lolita Syndrome'. Yet, surprisingly, it is not the text which Beauvoir originally wrote in French but a backtranslation from Frechtman's English translation effected by Francis and Gontier. ${ }^{20}$ The reason for such a translation trajectory remains unknown. Existing scholarship surmises that the original must have been lost, but no one has investigated why this has come about. I would argue that a number of contextual details were most certainly contributing factors. The passage of twenty years in a computerless society could explain the loss of a handwritten or typewritten manuscript. Alternatively, the only existing copy might have been in the 
possession of Frechtman, who had died more than a decade before the book was published in 1979. Most probably, however, the French original was forgotten because it was never considered a text in its own right. The article was commissioned for an American readership, and never intended for a French-speaking audience.

In the first stage of the process of back-translation, then, the French text loses its originatory status, instead fulfilling an auxiliary or relay function, a preparatory practice in anticipation of the second stage: the translated product. Why, in a third stage, the text should reappear back-translated into French in Francis and Gontier's volume some two decades later is also a point for consideration. A text which exposes the mechanics of patriarchal mythmaking as a counter-measure to recognizing women as autonomous, desiring beings, would have gained scant approval among a French male readership, a readership Beauvoir singles out as culpable. Only its temporal estrangement from the generation Beauvoir critiques, and its explicit labelling as a back-translation, and hence by implication an imported piece of foreign writing and thinking, makes the piece more palatable for a French audience in the 1980s.

A close comparative analysis of Frechtman's translation and its later back-translation into French reveals interesting insights into both sets of translators' praxis. It also bring us back to Beauvoir's original text. Francis and Gontier follow Frechtman's modus operandi, that is 'to set the source text into cultural motion'21 by 'domesticating' Beauvoir for her target audience, yet this time for a French audience. Firstly, Beauvoir's writing is stripped of its American vernacular as 'Mom' returns to 'mère' (mother), the 'cloud of ballyhoo' surrounding Bardot becomes the less tumultuous 'une enorme publicité' ('a great deal of publicity'), and instead of 'a conscious being who is sizing [the man] up', Beauvoir refers to Bardot as 'un être conscient qui le juge' ('a conscious being who judges him'). ${ }^{22}$ Not only do these translation choices neutralize Beauvoir's prose: they elevate it, removing an informality 
which would seem discordant for a readership already very familiar with her distinctive and measured style. Furthermore, upon reading the French back-translation, we can discern that it is a very literal translation of Frechtman's text. Francis and Gontier's back-translation does not deviate structurally or syntactically from Frechtman's work. Yet it does not come across as maladroit or unidiomatic in French, which in turn suggests that Frechtman's was also a very literal translation of Beauvoir's text - in some instances too literal, as an examination of Francis and Gontier's back-translation illuminates. Once back-translated into French, terms such as 'le nouveau roman' and 'l'éternel féminin' highlight that Frechtman had indeed adopted a very literal approach, the first phrase unfortunately appearing in his text as 'the young novel' and the second, forming Beauvoir's assertion that Vadim was responsible for the refashioning of the oldest of patriarchal myths, as follows: 'He invented a resolutely modern version of "the eternal female". ${ }^{23}$ While a translation such as 'the young novel' is lamentable, perhaps it would be unfairly critical to reprehend Frechtman for his choice given that the term was only coined in French by the critic Emile Henriot in $1957 .{ }^{24}$ Nevertheless, when read in a temporally removed context in which a term such as 'nouveau roman' is commonly identifiable as describing the famous French literary movement, Frechtman's choice becomes anachronistically jarring.

While such direct translations hampered meaning, other 'literalizations' more significantly distorted Beauvoir's philosophical discourse, a prime example being the translation of the term 'authenticity'. When translating Beauvoir's discussion of patriarchal attempts to control the Bardot persona, Frechtman refers to Bardot's genuine nature: 'Moral lapses can be corrected, but how could B.B. be cured of that dazzling virtue - genuineness? ${ }^{25}$ However, when rendered in French, the line reads as follows: 'Les fautes morales peuvent être corrigées, mais comment pourrait-on guérir B.B. de cette éblouissante vertu: l'authenticité ?'26 In her profiling of American men, Beauvoir also claims, in Frechtman's 
translation, that the American male 'feels a certain apathy to the "real woman", whereas Francis and Gontier once again make reference to authenticity: 'l'Américain éprouve une certaine antipathie pour "la femme authentique",.${ }^{27}$ If we are to assume that Frechtman's translation choices follow his preference for literal translation, and if we are to understand the terms he employs ('genuine' and 'real') as underpinning his understanding of authenticity, then he has obfuscated the existentialist philosophical meaning of the word, as unearthed by Francis and Gontier's back-translation. For authenticity is a key existentialist concept which Beauvoir deploys throughout her œuvre, especially in relation to her work on myths in $L e$ Deuxième Sexe. Here she shores up her argument that, due to women's limited freedom, ensuing in part from the patriarchal myths which have been constructed to control them, women's capacity to live authentically, freely, according to one's own beliefs and assuming responsibility for one's own actions, is compromised. Beauvoir tempers this existentialist concept with her phenomenologically informed elaboration of 'situation' in relation to women: the specificity of women's 'situatedness' within patriarchal culture is often the source of their complicity in their own subjection. Their self-dissimulation from the exigencies of existence, namely the responsibility which freedom engenders, is actualized when women live inauthentically or in 'bad faith', that is to say, hiding in an illusory absolute of prefabricated values and beliefs. According to Beauvoir, Bardot is so revolutionary because she threatens to dismantle patriarchal myths. By flaunting her sexual autonomy, she resists the fetishized body-object of the myth of the 'Eternal Feminine' forced upon her by heteropatriarchal order, thus living as an authentic woman. ${ }^{28}$ Overlooking this philosophical discourse, then, Frechtman buries the important genealogical link within Beauvoir's theory between Le Deuxième Sexe and the Bardot article, a crucial progression in Beauvoir's theorization of 'authenticity'. Beauvoir views Bardot's desiring consciousness as a potential solution to move women beyond the state of immanence they experience when acting in 'bad 
faith' which she describes in her exploration of female archetypes in Le Deuxième Sexe.

The trajectory of Beauvoir's article on Bardot does not end here, since in 2015 it appeared in Simone de Beauvoir: Feminist Writings, a volume edited by Margaret Simons and Marybeth Timmermann published by the University of Illinois Press grouping together Beauvoir's feminist writings, which include recently discovered texts from the era of $L e$ Deuxième Sexe as well as texts illustrating Beauvoir's pivotal role in struggles for sexual equality, homosexual rights, and women's rights in France. ${ }^{29}$ Frechtman's translation of Beauvoir's text on Bardot is not retranslated by Simons and Timmermann, but in notes following the text they map out its unusual trajectory and use this paratextual space to outline the changes they have made to Frechtman's translation along with their reasons for doing so. ${ }^{30}$ For example, they change Frechtman's reference to 'the young novel', observing: 'surely Beauvoir was referring to the "new novel" or "nouveau roman," which was a literary movement that emerged in the late 1950s challenging the traditional conventions of the novel with a new conception of time, plot, and character' ${ }^{31}$ As discussed earlier, such a modification clearly makes sense in a contemporary context, since the nouveau roman is now a firmly established and widely known French literary trend.

According to its editors, other changes in the anthology are motivated by a standardizing strategy. For example, towards the end of the article, when Beauvoir describes the evolving image of Bardot and the unsustainability of embodying the miscreant persona created in En cas de malheur (1958), then maps out other possible futures (more 'wholesome' ones) for Bardot instead, one of which involves a pastoral idyll, Simons and Timmermann modify Frechtman's reference to Bardot as a future 'farmerette', opting for 'the more standard "farmer woman" , ${ }^{32}$ Likewise, in Beauvoir's discussion of how spectators are perturbed about the way Bardot thwarts their voyeuristic, colonizing gaze, Simons and Timmermann alter Frechtman's 'they take revenge on her by running her down', opting 
instead for 'they take revenge on her by putting her down'. ${ }^{33}$ While both alterations arguably befit a more contemporaneous target audience, they nevertheless sit alongside some anachronistic turns of phrase employed by Frechtman, and thereby create an internal dissonance in the text. Both 'farmerette' and the expression 'running someone down' (i.e. criticizing someone, often unfairly) - resonate with the American dialect which Frechtman employs throughout the text. Although they look minor in isolation, the cumulative effect of such modifications by Simons and Timmermann works to dislodge Beauvoir's text from the era in which it was written.

Most significantly, Simons and Timmermann make specific alterations to Frechtman's translation in order to quash what they see as unwarranted essentialism:

Given's Beauvoir's rejection of essentialism, we have changed singular 'woman' to plural 'women' in cases where Beauvoir means all women or women in general in order to avoid essentialist connotations that Beauvoir would not have intended and to maintain consistency throughout the volume. ${ }^{34}$

Although they present this as a systematic editing strategy, it is curious that there are only two occurrences of it. In Beauvoir's comment about women's increasing social equality, Simons and Timmermann change Frechtman's phrasing from 'In an age when woman drives a car and speculates on the stock exchange' to 'In an age when women drive cars and speculate on the stock exchange' and similarly, they change 'The majority of Frenchmen claim that woman loses her sex appeal if she gives up her artifices' to 'The majority of Frenchmen claim that women lose their sex appeal if they give up their artifices. ${ }^{35}$ This modification makes sense insofar as it removes the monolithic conception of women suggested by Frechtman's text, most likely due to his literal translation: 'woman' deriving 
from 'la femme', which in French refers to both the generic and the universal. Yet why such an exaggerated editorial note should accompany these two isolated changes requires further attention.

Simon and Timmermann's note is indicative of a larger history involving Beauvoir and translation, and of a concomitant suspicion of the men who have brokered Beauvoir's passage into English. This narrative most famously arose in relation to the English translation of Le Deuxième Sexe by Howard Parshley in 1953. In fact, Margaret Simons was the first scholar to point out some of the serious cuts, omissions, and philosophical mistranslations, in her 1983 essay, 'The Silencing of Simone de Beauvoir: Guess What's Missing from The Second Sex, ${ }^{36}$ a ground-breaking piece of scholarship which was the springboard for discussions flagging yet more translation issues to do with the English text. ${ }^{37}$ Even though Frechtman's previous translation of Beauvoir's The Ethics of Ambiguity ${ }^{38}$ has received no such criticism and remains in print as the only English translation of Beauvoir's text, it seems that similar misgivings are attached to Frechtman's translation of the Bardot text here, in the wake of Parshley's misdemeanours. ${ }^{39}$ This distrust of Frechtman's translation is compounded by the volume editors in another editorial note in relation to his rendering of Beauvoir's sentence, 'A free woman is the very contrary of a light woman. ${ }^{40}$ Their note reads as follows:

This appears as 'a light woman' in the Esquire article, but we have changed it to 'easy woman' because Beauvoir surely wrote 'femme facile' here in keeping with her thoughts on this matter expressed in Le deuxième sexe. There, as Ellizabeth Fallaize points out in her introduction to this piece, 'In the penultimate chapter, "La femme indépendante" (The independent woman), Beauvoir lays out with some force the difficulty for women of establishing an independent sexual life, and denounces the 
confusion so often made in France between "femme libre" and "femme facile." , $L e$ deuxième sexe, vol. 2 (Paris: Gallimard, folio, 1949), 610. ${ }^{41}$

Their reasons for making this alteration are well justified here, and the theoretical symbiosis between Beauvoir's argument on Bardot and her philosophical discourse on women in Le Deuxième Sexe is strikingly clear. Frechtman's word choice here ('light') is the discordant result of a literal translation rather than an idiomatic phrase conjuring the image of an 'easy woman' - unless, of course, it reminded him of Adrian Brunel's 1928 film, A Light Woman, but to conjecture so would be far too tangential a leap. While on the one hand, the editors' decision seems prudent given the semantic context, their assumption, on the other hand, about what Beauvoir 'surely wrote' stands on less solid ground. In a plot twist which takes this study into the rooms of an auction house, we will discover why.

On 21 May 2008, various lots from a collection owned by Fernande Gontier went under the hammer in Sotheby's Paris auction house. Among them was Lot 97, a corrected typescript of Francis and Gontier's French back-translation of 'Brigitte Bardot and the Lolita Syndrome' from 1978 to be sold with an estimate of $€ 2,000-€ 3,000$. Sotheby's online catalogue describes the typescript as covered with edits ("portant de très nombreuses ratures dans le texte corrigées au crayon'), having been reworked by Simone de Beauvoir, who dictated the corrections to Claude Francis. This tallies with Francis and Gontier's acknowledgements at the beginning of Les écrits de Simone de Beauvoir, where they thank her for her support and encouragement throughout the project as well as for the numerous meetings she had with them over the course of two years, generously supplying them with indispensable information and details. ${ }^{42}$ In the image displayed on Sotheby's website, ${ }^{43}$ only the first and final pages of the typescript are fully visible, with partial glimpses of pages 2 and 5. The visible pages are covered, in pencil, with crossings-out and additions scribbled above. 
Although quite difficult to discern, a closer look at the revisions shows that the majority were simply stylistic or syntactical rearrangements. For example, in the sentence 'Quand le film Et Dieu créa la femme fut presenté', the passive, preterite tense is rearranged as 'Quand on a projété Et Dieu créa la femme'. Elsewhere, 'en dépit de cela' is replaced with the more concise synonym 'mais', and the sentence 'Mais, plus que tout, c'est sa franchise qui dérange le public et enchante les Américains' is syntactically rearranged as 'C'est sa franchise qui, plus que tout, dérange le public français et enchante les Américains', whereby Beauvoir specifies that the disturbed public she was referring to was the French public ('le public français'). At no point on these two visible pages does Beauvoir drastically rework or rewrite the text in any way, but, most importantly for our argument, the following handwritten note and signature appears at the bottom of the final page: 'Text retranslated from the English with my agreement. Read and approved. S. de Beauvoir.' ${ }^{44}$

The latter inscription stands as tangible proof that Beauvoir read and endorsed this back-translation. Recurring to Francis and Gontier's back-translation, then, we can establish that, in French, Beauvoir does talk about 'une femme légère'. Whether this was what Beauvoir originally wrote in the 1950s will ultimately never be known, but her signature on the manuscript of the back-translation signals that she was happy with this wording at that particular moment. Another point which supports the hypothesis that Beauvoir did, in fact, originally write 'une femme légère' is that, on every other occasion where the word 'facile' appears in the text, Frechtman translates it as 'easy' or 'easy-going'. Given how literal his translation is, it would be in keeping that he would have translated 'légère' literally as 'light', instead of opting for a more common French phrase such as 'une femme de mœurs légères', meaning 'a woman of easy virtue'. This argument does not change the fact that Frechtman's overly literal translation choice here was ill fitting. But Simons and Timmermann's comment, whereby they claim to know what Beauvoir 'surely wrote', throws a sobering light on the 
way authoriality is often automatically attributed to source texts (even without concrete evidence), which only accentuates asymmetrical relationships between original texts and translations. Beauvoir's stamp of approval on this back-translation indeed opens up a wide array of questions in relation to the process of back-translation and how far it leads us to reconsider the relationship between an original and its translation. Does it mean that this back-translation 'leapfrogs' over the English translation, that it should retrospectively assume the status of original text, having been written in Beauvoir's maternal tongue and approved by her? Does it suggest that the notion of 'original' is open to shifts and mutations as we move through different cultural and temporal spaces?

Speaking in Beauvoirian terms and in accordance with Hegel's master-slave dialectic, the self does not exist without recognition of the Other; only a mutually constituting, dialogic flow of acknowledgment can allow master/slave, self/Other, or original/translation, to coexist. Yet with back-translations, potential asymmetries such as those Beauvoir spotlights in self/Other relations, highlighting women's position within a heteropatriarchal order, are dismantled. Back-translations prompt us to reimagine what translation really is. Freeing us from the finite boundaries of source and target texts, back-translations allow us to conceive of translation as a fluidity, an unfurling and evolving story which can criss-cross cultural and temporal spaces without becoming trapped in a singular moment or entrenched in a singular definition. Like returning travellers, back-translations journey homewards, yet not to regain their origins; instead they are changed, indelibly altered by the experience of the foreign, and porous to new vistas of understanding.

One final important consideration in this study of the evolution of Beauvoir's text on Bardot is the role played by images, and the dialogue, constructive or otherwise, which they create with Beauvoir's thought in the various iterations of the text. Unsurprisingly, given the subject of the essay and its initial appearance in a magazine, sumptuous full-size pictures 
adorn and punctuate Beauvoir's text. The three photographs, taken by renowned American fashion photographer Richard Avedon, capture Bardot in seductive poses. If we consider these photographs as examples of intersemiotic translation - which Roman Jakobson defined as 'an interpretation of verbal signs by means of signs of non-verbal sign systems' 45 - then it is important to consider how these photographs translate or mistranslate Beauvoir's discourse. On the one hand, the three photographs very well translate the myth of Bardot, which Beauvoir's text theorizes. The images are coquettish: the one in which she is pulling down the neck of her sweater is seductive, and the photograph of her naked, wrapped in a French flag, resonates with Beauvoir's classifying her as an important French cultural export. Yet, as certain scholars argue, such sensuous, pin-up-style shots can obfuscate Beauvoir's argument. As Kemper contends, 'Beauvoir's analysis strives to unveil the clear female agency behind the gauzy images, even as some of her text finds itself graphically buried under a suggestively supine Bardot, draped across a two-page spread like wide-screen sinerama. ${ }^{46}$ In this sense, it could be argued that the images mistranslate Beauvoir's discourse by using submissive corporeality as a marketing apparatus for the text. However, what Kemper's observation misses is the way in which Bardot meets the gaze of the camera in each of the pictures. Her arresting stare reinforces Beauvoir's central idea, that the Bardot persona is different because she refuses to submit to the position of body-object that the male gaze tries to force upon her.

Unfortunately, this intersemiotic translation of Beauvoir's discourse on Bardot's erotic subjective agency is not found in any of the reprints of the text; Frechtman's English translation is reproduced verbatim, but not accompanied by the same pictures as in the Esquire article. ${ }^{47}$ In these reprints, the images of Bardot, courtesy of various photographers, publishers, and magazines, present her as the fetishized body-object, emphasizing the nude, pin-up Bardot. Included are various shots of her in underwear and in bikini bottoms pulled 
down to reveal her buttocks, as well as an image of her left breast spilling out of a swimsuit. ${ }^{48}$ Just as disconcerting as this photographic portrayal of the Bardot persona is the way in which these images are positioned in relation to Beauvoir's text. For example, in the 1972 reprint by Arno Press, each page of Beauvoir's essay is punctuated by a different headshot, and the text is followed by many full-page pictures of Bardot captured both on and off screen. This fragmentation of Bardot's image followed by the full-length shots inviting a male gaze upon her body culminate in a presentation, which Sylvie Blum-Reid views as 'becom[ing] in turn a questionable commodity just like Bardot herself' ${ }^{49}$ Furthermore, Beauvoir's text has been randomly extracted and appended to these full-page images, and in most instances in a counterproductive way. For example, in Beauvoir's extracted quotation, 'when she strips, she is not unveiling a mystery. She is showing her body, neither more nor less', the image shown is of a naked Bardot with her back to the camera, precisely not showing her body. Unaware of the voyeuristic gaze this composition invites, she becomes the mystery. Similarly, on the opposite page, the extracted quotation reads: 'Her eroticism is not magical, but aggressive., ${ }^{50}$ Yet Bardot's autonomous sexual desire is negated by a picture showing her in a missionary position beneath the embrace of a man kissing her. Such juxtapositions visibly undo Beauvoir's discourse by reintroducing a male gaze turned upon Bardot.

However, neither in Francis and Gontier's French back-translation, nor in Simons and Timmermann's edited English version, do images of Bardot appear. This, of course, could have been due to copyright issues, or simply to the two books being conceived as scholarly in scope or ethos. In both volumes, the focus is indeed squarely on Beauvoir and her writing, whereas in the Esquire publication and the Arno edition, the focus is on Bardot. Yet excluding the photographs prevents readers from learning something important about Beauvoir herself. The images, even the more problematic fragmented ones, remind us of Beauvoir's position as consumer and voyeur of the Bardot persona too. As Blum-Reid states, 
'Beauvoir implicitly projects her own gaze as a female spectator', ${ }^{51}$ reminding us of the tension between Beauvoir's interpretation of the Bardot figure as a subjective agent but, at the same time, as an object of the camera. As Vincendeau points out, 'All her films involve moments of pure spectacle that stop the flow of the narrative. She is typically frozen in postures which allow the spectator to admire her body and face. ${ }^{52}$ Beauvoir's double-bind position as both disrupter and consumer of the male gaze could be seen as problematic, and is perhaps another reason for the photographs being omitted from the French back-translation and the revised English reprint within the anthology. This highlights the way in which, with regard to back-translation, intersemiotic translation can be temporally contingent. Intended for a different audience, separated temporally and ideologically from Beauvoir's Esquire readers, both the French back-translation and the revised English reprint distance Beauvoir from the intersemioticism which snapshoted her as a film critic, to emphasize, instead, her philosophical gaze. Yet by losing this intersemiotic dimension which visualizes Beauvoir's position as spectator, we lose with it the possibility of fully understanding how she envisages other ways of seeing the Bardot persona; that is, through a matrixial gaze de-hierarchizing the gendered gazer/object binary, inviting readers to consider the co-emergence of subjectivities. $^{53}$

For now, we draw our study of Beauvoir, Bardot, and the back-translation to a close, but it is a story which could be unfinished, for who knows whether Beauvoir's work will appear again, back-translated for a different audience in a different cultural moment? This textual analysis has underscored the important role which translators play as cultural mediators, skilfully fashioning writers and their texts so that they are propitiously received on foreign terrains. For his Esquire readers, Frechtman imbued Beauvoir's prose with an appealingly American lilt, as Francis and Gontier did, returning Beauvoir to her more recognizable measured French style. Yet, as with all narratives of translation, there are tales 
of both losses and gains: what Frechtman missed in Beauvoir's feminist philosophical discourse in English is restored through its French back-translation, but in turn, due to the lack of an accompanying intersemiotic translation, the French back-translation loses the possibility of fully apprehending Beauvoir's reimagining of the gaze. Most importantly, the existence and practice of back-translations allows us to envision positions beyond source and target texts, reframing translation as a process, a continuum revivifying texts like Beauvoir's. Ultimately, Beauvoir's work on Bardot is all about myths, and hopefully, just as Beauvoir exposes the weaknesses of the Bardot myth by presenting it as a reworking of the 'Eternal Feminine', through charting the trajectory of Beauvoir's fascinating text, so has this study succeeded in dismantling another myth. For if we imagine literary translations as textual body-objects, like the transgressive Bardot, the transgressive process of back-translation threatens to explode any master-narratives seeking to position translations as Absolute Others for 'untouchable' originals. As Beauvoir aptly writes, 'As soon as one myth is touched, all myths are in danger. ${ }^{54}$

Newcastle University

\footnotetext{
${ }^{1}$ Elizabeth Fallaize, 'Reception problems for women writers: The case of Simone de Beauvoir', in Women and Representation, edited by Diana Knight and Judith Still (London, 1995), pp. 43-56 (p. 43).

${ }^{2}$ Lauren Du Graf, 'Cinema in the eyes of Simone de Beauvoir', Screen, 59.3 (2018), 381-90 (p. 381).

${ }^{3}$ Simone de Beauvoir, 'Brigitte Bardot and the Lolita Syndrome', Esquire (August 1959; hereafter 'Beauvoir, Esquire'), pp. 32-8.

${ }^{4}$ Simone de Beauvoir, 'Bardot et le syndrome de Lolita', in Les Écrits de Simone de Beauvoir, edited and translated by Claude Francis and Fernande Gontier (Paris, 1979), pp.
} 
363-76 (hereafter 'Beauvoir, Bardot et le syndrome'). Simone de Beauvoir: Feminist Writings, edited by Margaret Simons and Marybeth Timmermann (Urbana, IL, 2015), pp. 114-26.

${ }^{5}$ Ginette Vincendeau, Brigitte Bardot (London, 2013), p. 5.

${ }^{6}$ Kelley Conway, 'Brigitte Bardot: From International Star to Fashion Icon', in New Constellations: Movie Stars of the 1960s, edited by Pamela Robertson Wojcik (New Brunswick, NJ, 2012), pp. 183-201 (p. 188).

${ }^{7}$ Ursula Tidd, Simone de Beauvoir (London, 2004), p. 45.

${ }^{8}$ Beauvoir, Esquire, p. 34.

${ }^{9}$ Simone de Beauvoir, The Second Sex, translated by Constance Borde and Sheila MalovanyChevallier (London, 2011), p. 158.

${ }^{10}$ Beauvoir, Esquire, p. 36.

${ }^{11}$ Beauvoir's text is important not only as an early example of stardom scholarship, but also because her deconstruction of the male gaze anticipates some of the early tenets of feminist film theory, a prime example being Laura Mulvey’s seminal essay, 'Visual Pleasure and Narrative Cinema', in The Feminism and Visual Culture Reader, edited by Amelia Jones (London, 2003), pp. 44-53.

${ }^{12}$ Beauvoir, Esquire, p. 36.

13 Tom Kemper, 'New Wave/New Woman', Simone De Beauvoir Studies, 19 (2002), 102-15 (p. 102).

${ }^{14}$ Kemper, p. 104.

${ }^{15}$ Denise Warren, 'Beauvoir on Bardot: The Ambiguity Syndrome', Dalhousie French Studies, 13 (1987), 39-50 (p. 39).

16 'Bernard Frechtman Genet's Translator', New York Times, 29 March 1967, p. 45. 
${ }^{17}$ Stacy Keltner, 'Beauvoir's Idea of Ambiguity', in The Philosophy of Simone de Beauvoir: Critical Essays, edited by Margaret Simons (Bloomington, IN, 2006), pp. 201-13 (p. 201). ${ }^{18}$ Beauvoir, Esquire, pp. 33-4.

${ }^{19}$ Beauvoir, Esquire, p. 36.

${ }^{20}$ Beauvoir's Bardot text is not the only back-translation to feature in Francis and Gontier's volume. In the third section entitled 'Textes', there are seven other back-translations comprising pieces such as translated articles Beauvoir wrote for newspapers and magazines, as well as prefaces to books and her interview with John Gerassi for Society in 1976. The editors mark their back-translations in the volume with the indication 'traduit de l'anglais', but they do not give any details about who originally translated the texts into English. This information is not always easily trackable, but in other instances, such as Beauvoir's article 'Jean-Paul Sartre: Strictly Personal' for Harper’s Bazaar, 1946, (translated by Malcolm Cowley), details of who the translator was are readily available.

${ }^{21}$ Myriam Díaz-Diocaretz, Translating Poetic Discourse: Questions on Feminist Strategies in Adrienne Rich (Amsterdam, 1985), p. 2.

${ }^{22}$ Beauvoir, Esquire, pp. 36, 34, 36; Beauvoir, 'Bardot et le syndrome', pp. 370, 364, 369.

${ }^{23}$ Beauvoir, 'Bardot et le syndrome', pp. 371, 364; Beauvoir, Esquire, pp. 36, 34.

${ }^{24}$ Emile Henriot, 'La Jalousie, d'Alain Robbe-Grillet; Tropismes, de Nathalie Sarraute', Le Monde, 22 May 1957, p. 8.

${ }^{25}$ Beauvoir, Esquire, p. 34.

${ }^{26}$ Beauvoir, 'Bardot et le syndrome', p. 368.

${ }^{27}$ Beauvoir, Esquire, p. 36 ; Beauvoir, 'Bardot et le syndrome', p. 370.

${ }^{28}$ For an analysis of the challenges related to translating the philosophical concept of 'authenticité' in Le Deuxième Sexe, see Marlène Bichet, 'Exploring the translation of feminist 
philosophy: Simone de Beauvoir's Le Deuxième Sexe' (unpublished doctoral thesis,

University of Salford, 2017).

${ }^{29}$ See n. 4, above.

${ }^{30}$ Eight endnotes accompany the text, seven of which outline specific changes made, while the other one provides some contextual details about Marc Allegret and Roger Vadim.

${ }^{31}$ Feminist Writings, p. 125.

${ }^{32}$ Beauvoir, Esquire, p. 38; Feminist Writings, p. 125.

${ }^{33}$ Beauvoir, Esquire, p. 38; Feminist Writings, p. 122.

${ }^{34}$ Feminist Writings, p. 125.

${ }^{35}$ Beauvoir, Esquire, p. 34, 36; Feminist Writings, p. 115, 119.

${ }^{36}$ Margaret A. Simons, 'The Silencing of Simone de Beauvoir: Guess What's Missing from The Second Sex', Women's Studies International Forum, 6.5 (1983), 559-64.

37 Toril Moi, Sexual/Textual Politics: Feminist Literary Theory (London, 1985).

${ }^{38}$ Simone de Beauvoir, The Ethics of Ambiguity, translated by Bernard Frechtman (New York, 1948).

${ }^{39}$ Anna Bogic's article goes some way to redress the balance of the criticism attributed to Parshley, explaining, via archival evidence, how many of the changes made were at the behest of the editor. See Anna Bogic, 'Why Philosophy Went Missing: Understanding the English Version of Simone de Beauvoir's Le Deuxième Sexe', in Translating Women, edited by Luise von Flotow (Ottawa, 2011), pp. 151-67.

${ }^{40}$ Beauvoir, Esquire, p. 36.

${ }^{41}$ Feminist Writings, p. 125.

${ }^{42}$ Les écrits de Simone de Beauvoir, p. 12.

$43<$ https://www.sothebys.com/en/search-results.html?query=bardot\%20beauvoir $>$ (accessed 21 January 2020). 
44 'Texte retraduit de l'anglais avec mon approbation. Lu et approuvé. S. de Beauvoir'; my translation.

${ }^{45}$ Roman Jakobson, 'On Linguistic Aspects of Translation', in On Translation, edited by Reuben Brower (Cambridge, MA, 1959), pp. 232-39 (p. 233).

${ }^{46}$ Kemper, p. 102.

${ }^{47}$ The text has been reprinted along with photographs four times to date: by André

Deutsch/Weidenfeld \& Nicolson (London, 1960); Reynal \& Co. (New York, 1960); as a Foursquare edition from the New English Library (London, 1962); and by Arno Press (New York, 1972).

${ }^{48}$ In the Foursquare edition, this arresting image of the Bardot persona with exposed buttocks appears in differing iterations on pages 17, 19, 21, and 27.

${ }^{49}$ Sylvie Blum-Reid, 'Simone De Beauvoir And Visual Pleasure', Simone De Beauvoir Studies, 14 (1997), 140-8 (p. 145).

${ }^{50}$ Simone de Beauvoir, Brigitte Bardot and the Lolita Syndrome (New York, 1972); only Beauvoir's article is paginated at the beginning of this edition.

${ }^{51}$ Blum-Reid, p. 144.

${ }^{52}$ Ginette Vincendeau, Stars and Stardom in French Cinema (London, 2000), p. 94.

${ }^{53}$ On this subject see further Bracha Ettinger, The Matrixial Gaze (Leeds, 1995).

${ }^{54}$ Beauvoir, Esquire, p. 38. 